\title{
Work-Related Behaviors and Experience Patterns of Physical Education Teachers According to the Individually Burnout Factors
}

\author{
Ramazan Taşçığlu (Corresponding author) \\ Graduate School of Health Sciences, Anadolu University, Eskişehir, Turkey; \\ Department of Physical Education and Sports Teaching, Faculty of Sport Sciences \\ Eskişehir Technical University, Tepebaş1, Turkey \\ E-mail: ramazantascioglu@windowslive.com
}

\begin{abstract}
Serdar Kocaekşi
Department of Physical Education and Sports Teaching, Faculty of Sport Sciences

Eskişehir Technical University, Tepebaşı, Turkey

E-mail: skocaeksi@eskisehir.edu.tr

Melih Balyan

Department of Physical Education and Sports Teaching, Faculty of Sport Sciences

Ege University, Izmir, Turkey

E-mail: melih.balyan@ege.edu.tr
\end{abstract}

Received: September 12, 2020

Accepted: November 2, 2020

Published: November 17, 2020

doi:10.5296/jei.v6i2.17675

URL: https://doi.org/10.5296/jei.v6i2.17675

\begin{abstract}
Teachers who interact directly with people were evaluated one of risk groups of burnout syndrome. The aim of this research was to determine work-related behaviors and experience patterns of physical education teachers and to analyze them according to the individually burnout factors. A total of 179 physical education teachers, $98(54.7 \%)$ males and $81(45.3 \%)$
\end{abstract}


females who worked during 2012-2013 academic year in İzmir participated in the study. "Work-Related Behavior and Experience Patterns Scale" was used in this study. The data collection was analyzed with reliability analysis, descriptive analysis, Independent Sample $t$ Test, and Pearson correlation. It was found that 10 (5.6\%) were in "Type B" exhaustion group, 45 (25.1\%) were "Type A" hyper devotion individuals, 33 (18.4\%) were in "Type S" heedless attitude group, and $91(50.8 \%)$ were in "Type G" healthy group among the physical education teachers. It was found that work-related behaviors and experience patterns of physical education teachers vary significantly in terms of institution, gender, and marital status at several dimensions. According to correlation analysis results, there was a significant relationship between age, professional experience, and work-related behaviors and experience patterns at several dimensions.

Keywords: Physical education teacher, AVEM, Burnout, Occupational health

\section{Introduction}

Countries are constantly striving to improve their education systems and schools in order to reach higher values in line with their social and economic expectations. Teachers are at the center of schools as the most important and most valuable resource. For this reason, countries make the utmost effort to develop teachers' knowledge and skills, to select and employ them, and make this issue their top priority (OECD, 2005). However, in the last 30 years, teachers' professional lives have become more and more complex and intense (Brante, 2009). Studies both abroad (OECD, 2005) and in Turkey (Kiremitci \& Gençer, 2014) reveal that teachers are both professionally discredited and questioned and worn out individually.

Physical education teachers feel that the importance given to their profession by community has decreased due to these developments. In addition to these, extra roles given to physical education teachers such as disciplinary responsibility and branch coaching increase the number of obstacles that consume physical education teachers' energy (Fejgin, Ephraty, \& Ben-Sira, 1995). Teachers, who are employees of the education field, which is among the areas that generate the most stress compared to other professions (Jepson \& Forrest, 2006), use all their knowledge and skills to overcome the obstacles they encounter (Kieschke \& Schaarschmidt, 2008). Many studies have evaluated teachers who interact directly with people among risk groups of burnout syndrome (Brudnik, 2009; Grayson \& Alvarez, 2008). Although it has been revealed that participation in physical activities and sports contributes positively to the cognitive, emotional and psychomotor development of both children and young people (Demirhan, 2006), the importance given to physical education classes in schools has been reduced and neglected due to the competitive environment created by today's conditions (Pirrie \& Lodewyk, 2012). Pierre and Lodewyk (2012), describes today's conditions as a competitive school environment where academic success is possible with less physical activity. Due to the constantly renewed educational policies (such as $4+4+4$ Continuous Compulsory Education), teachers' changing responsibilities also change the stress they experience (Doğan, Demir, \& Pınar, 2014). For this reason, researching how teachers are affected by occupational burnout syndrome (Maslach, 1982) and later approaches (Arbeitsbezogenes Verhaltens und Erlebensmuste-AVEM) (Schaarschmidt \& Fischer, 1997) 
maintains its popularity. Because of its importance, there are studies that investigate professional qualifications of physical education teachers (Sucuoglu \& Atamturk, 2020) and examine them with profession perspective (Alkan, Yildiz, \& Bakir, 2011; Arıkan, 2020; Jepson \& Forrest, 2006; Kaya \& Erdoğan, 2020; Kiremitçi, Gençer, \& Demiray, 2014; Koustelios \& Tsigilis, 2005).

In this study, the AVEM theoretical approach is used to determine the behavior and life models of a profession. This approach makes it possible to group members of that occupational group under certain types, on the other hand, to comment in terms of the reasons for their inclusion under those types (Schaarschmidt \& Fischer, 2011). The aim of this study is to determine the types of physical education teachers and to test the relationship between gender, marital status, institution, age, and experience variables.

\section{Method}

\subsection{Research Model}

A descriptive survey model (Büyüköztürk, Çakmak, Akgün, Karadeniz, \& Demirel, 2016) was implemented in this study. Gender, marital status, and institution coded categorical variables and age and experience in service coded continuous were independent variables.

\subsection{The Universe and Sample of the Research}

The universe of the research was physical education teachers who worked in public and private schools during 2012-2013 academic year in İzmir Province. A total of 179 physical education teachers, $98\left(\overline{\mathrm{X}}_{\mathrm{age}}=37.38 \pm 9.20\right)$ males and $81\left(\overline{\mathrm{X}}_{\mathrm{age}}=35.87 \pm 8.50\right)$ females participated in the study. Demographic information of participants are presented in Table 1.

Table 1. Demographics of study sample

\begin{tabular}{|l|l|l|l|}
\hline \multirow{3}{*}{ Gender } & & $\mathbf{n}$ & $\mathbf{\%}$ \\
\hline \multirow{3}{*}{ Marital Status } & Male & 98 & 54.7 \\
\cline { 2 - 4 } & Female & 81 & 45.3 \\
\hline \multirow{3}{*}{ Institution } & Married & 103 & 57.5 \\
\cline { 2 - 4 } & Single & 76 & 42.5 \\
\hline & Public & 68 & 38 \\
\cline { 2 - 4 } & Private & 111 & 62 \\
\hline
\end{tabular}

\subsection{Data Collection Tools}

\subsubsection{Demographic Form}

Gender, marital status, institution, age and experience in service were obtained as 
demographic data by self-reported. These variables are among the individual factors affecting the burnout (Dalkılıç, 2014)

\subsubsection{Work Related Behavior and Experience Pattern Scale}

The scale developed by Schaarschmidt and Fischer (1997) was adopted to Turkish by Gençer et al. (2010). The scale is based on resource-oriented theories to assess behavior and experience in relation to work and occupational requirements.

The aim is to identify different lifestyle models in the way people deal with these requirements. The scale has 66-item 5-point Likert-type scale (from "I don't agree at all [1]" to "I totally agree [5]") explaining work related behaviors and experiences (Item 1: Work is the most important element in my life). The scale consists of 11 dimensions "experience of social support (ESS), satisfaction with life (SL), satisfaction with work (SW), balance and mental stability (BMS), offensive coping with problems (OCP), resignation tendencies (RT), emotional distancing (ED), striving for perfection (SP), tendency to exert (TE), professional ambition (PA), and subjective significance of work (SSW)". These dimensions all together display four different work-related behaviors and experience lifestyle models. These are Type B risk group (Burnout-Exhaustion), Type A risk group (Risiko i.der SelbstüberforderungHyper devotion), Type S (Schonung-Heedless Attitude), and Type G (Gesundheit-Beautiful Health) lifestyle models. The four types described in Table 2 (Gençer et al., 2010; Schaarschmidt \& Fischer, 1997, 2011).

Table 2. The four work-related behavior and experience patterns described by the AVEM

\begin{tabular}{|c|c|}
\hline Group & \\
\hline $\begin{array}{l}\text { Risk Type B } \\
\text { (Exhaustion Group) }\end{array}$ & $\begin{array}{l}\text { Strong tendency towards resignation and reduced mental resilience. } \\
\text { Extremely limited job satisfaction. }\end{array}$ \\
\hline $\begin{array}{l}\text { Risk Type A } \\
\text { (Hyper Devotion Group) }\end{array}$ & $\begin{array}{l}\text { Intense involvement and lack of dissociation from work-related problems. } \\
\text { Have limited enjoyment of life and job satisfaction. }\end{array}$ \\
\hline $\begin{array}{l}\text { Type S } \\
\text { (Heedless Attitude Group) }\end{array}$ & $\begin{array}{l}\text { Not having very strong commitment to their profession. Lack of involvement } \\
\text { with work coupled with strong dissociation from problems dealing with the } \\
\text { work. }\end{array}$ \\
\hline $\begin{array}{l}\text { Type G } \\
\text { (Healthy Group) }\end{array}$ & $\begin{array}{l}\text { High but not excessive involvement with work, resilience with regard to } \\
\text { pressure and stress, positive attitudes towards their profession and life } \\
\text { (emotional health). }\end{array}$ \\
\hline
\end{tabular}

\subsubsection{Data Collection Procedure}

Following the ethical approval which was obtained by the Ethics Committee of Ege University, the study was initiated. Data were collected by the same researcher using the convenience sampling method (Büyüköztürk et al., 2016) in all data collection centers. 


\section{Macrothink}

The same researcher followed individual and group face-to-face survey method procedure (Büyüköztürk et al., 2016) with physical education teachers who wanted to participate voluntarily. In the process of data collection, the information related to the content of the study, rights of the participants and information of the researchers were provided to the participants and "Voluntary Consent Form" was taken.

\subsubsection{Data Analysis}

Data analysis was conducted from 179 surveys. Before the analysis, variables were examined to meet the assumptions of parametric tests. The results showed that the skewness and kurtosis values were between \pm 1 criterion intervals (Tabachnick \& Fidell, 2013). Independent sample t-tests were conducted to understand differences between "gender", "marital status", and "institution" variables. In addition, Pearson correlation analysis was conducted to understand the relation between age, experience in service, and scores of all dimensions.

In Gençer et al. (2010) study, confirmatory factor analyses were conducted to test validity of the scale and it was validated with satisfactory scores. Cronbach's alpha values were checked for internal consistency and it was found that scores of sub-dimensions ranged from .56 (Experience of social support) to .78 (Tendency to exert) (Table 3). Cronbach Alpha values showed that scale dimensions have high, medium, and low level internal consistency (Kalayc1, 2016).

IBM SPSS 22.0 (Chicago, IL) was used for analyses. The significance level was determined to be .05 .

Table 3. Cronbach's alpha $(\alpha)$ coefficients

\begin{tabular}{|l|l|}
\hline Dimensions & Cronbach's alpha $(\boldsymbol{\alpha})$ \\
\hline Work Related Behavior and Experience Patterns Scale & .87 \\
\hline Subjective Significance of Work & .72 \\
\hline Professional Ambition & .63 \\
\hline Tendency to Exert & .78 \\
\hline Striving for Perfection & .77 \\
\hline Emotional Distancing & .61 \\
\hline Resignation Tendencies & .71 \\
\hline Offensive Coping with Problems & .69 \\
\hline Balance and Mental Stability & .72 \\
\hline Satisfaction with Work & .64 \\
\hline Satisfaction with Life & .65 \\
\hline Experience of Social Support & .56 \\
\hline
\end{tabular}




\section{1) Macrothink}

\section{Results}

When the distributions of physical education teachers according to AVEM types was examined; it was found that $50.8 \%$ were in Type G, $18.4 \%$ in Type S, $25.1 \%$ were Risk Type A and 5.6\% were in Risk Type B. Distributions of percentages and frequency of physical education teachers' four AVEM models and their institution, gender, and marital status were given in Table 4.

Table 4. The distribution of AVEM types of the study sample

\begin{tabular}{|l|l|l|l|l|l|l|}
\hline & & $\mathbf{n}$ & $\begin{array}{l}\text { Type G } \\
\text { (Healthy } \\
\text { Group) }\end{array}$ & $\begin{array}{l}\text { Type S } \\
\text { (Heedless } \\
\text { Attitude Group) }\end{array}$ & $\begin{array}{l}\text { Type A } \\
\text { (Hyper } \\
\text { Devotion Group) }\end{array}$ & $\begin{array}{l}\text { Type B } \\
\text { (Exhaustion } \\
\text { Group) }\end{array}$ \\
\hline \multirow{2}{*}{ Total } & & 179 & $91(50.8 \%)$ & $33(18.4 \%)$ & $45(25.1 \%)$ & $10(5.6 \%)$ \\
\hline \multirow{3}{*}{ Gender } & $\mathrm{M}$ & 98 & $58(59.2 \%)$ & $19(19.4 \%)$ & $21(21.4 \%)$ & $0(0 \%)$ \\
\cline { 2 - 7 } & $\mathrm{F}$ & 81 & $33(40.7 \%)$ & $14(17.3 \%)$ & $24(29.6 \%)$ & $10(12.3 \%)$ \\
\hline \multirow{3}{*}{ Marital Status } & $\mathrm{M}$ & 103 & $55(53.4 \%)$ & $17(16.5 \%)$ & $24(23.3 \%)$ & $7(6.8 \%)$ \\
\cline { 2 - 7 } & $\mathrm{S}$ & 76 & $36(47.4 \%)$ & $16(21.1 \%)$ & $21(27.6 \%)$ & $3(3.9 \%)$ \\
\hline \multirow{2}{*}{ Institution } & $\mathrm{P}_{1}$ & 68 & $28(41.2 \%)$ & $15(22.1 \%)$ & $21(30.9 \%)$ & $4(5.9 \%)$ \\
\cline { 2 - 7 } & $\mathrm{P}_{2}$ & 111 & $63(56.8 \%)$ & $18(16.2 \%)$ & $24(21.6 \%)$ & $6(5.4 \%)$ \\
\hline
\end{tabular}

Note. Gender ( $\mathrm{M}=$ Male, $\mathrm{F}=$ Female); Marital Status $(\mathrm{M}=$ Married, $\mathrm{S}=$ Single); Institution $\left(\mathrm{P}_{1}=\right.$ Public, $\mathrm{P}_{2}=$ Private $)$.

The independent samples $t$ test revealed that average of male teachers $(\overline{\mathrm{X}}=6.74 \pm 1.48)$ was significantly higher than the average of female teachers $(\bar{X}=5.19 \pm 2.01)$ on balance and mental stability $\left(t_{177}=5.78, \mathrm{p}<.00\right)$ (Table 5$)$. 
Table 5. Means, standard deviations and independent t-test results for gender

\begin{tabular}{|l|l|l|l|}
\hline \multirow{2}{*}{ Work Related Behavior and Experience Patterns } & \multicolumn{2}{|c|}{ Gender } & \multirow{2}{*}{ t } \\
\cline { 2 - 3 } & Male (n=98) & Female (n= 81) & \\
\hline Subjective Significance of Work & $6.67 \pm 1.51$ & $6.62 \pm 1.75$ & .23 \\
\hline Professional Ambition & $6.17 \pm 1.71$ & $6.01 \pm 1.72$ & .62 \\
\hline Tendency to Exert & $5.77 \pm 1.86$ & $5.52 \pm 1.91$ & .87 \\
\hline Striving for Perfection & $5.81 \pm 1.95$ & $5.95 \pm 1.92$ & -.49 \\
\hline Emotional Distancing & $5.06 \pm 1.43$ & $4.75 \pm 1.60$ & 1.35 \\
\hline Resignation Tendencies & $4.12 \pm 1.78$ & $4.31 \pm 1.77$ & -.69 \\
\hline Offensive Coping with Problems & $5.43 \pm 1.70$ & $5.20 \pm 2.02$ & .82 \\
\hline Balance and Mental Stability & $6.74 \pm 1.48$ & $5.19 \pm 2.01$ & $5.78^{* * *}$ \\
\hline Satisfaction with Work & $5.40 \pm 1.67$ & $5.59 \pm 1.87$ & -.73 \\
\hline Satisfaction with Life & $5.72 \pm 1.55$ & $5.38 \pm 1.80$ & 1.35 \\
\hline Experience of Social Support & $4.35 \pm 1.52$ & $4.75 \pm 1.65$ & -1.70 \\
\hline
\end{tabular}

Note. $* * * \mathrm{p}<.0001 ; * * \mathrm{p}<.001 ; * \mathrm{p}<.05, \mathrm{p}>.05$.

Significance differences were found between married and single physical education teachers in terms of their scores on balance and mental stability $\left(t_{177}=-2.08, \mathrm{p}<.05\right)$ and satisfaction with life $\left(t_{177}=2.40, \mathrm{p}<.05\right)$ (Table 6). 
Table 6. Means, standard deviations and independent t-test results for marital status

\begin{tabular}{|l|l|l|l|}
\hline \multirow{2}{*}{ Work Related Behavior and Experience Patterns } & \multicolumn{2}{|c|}{ Marital Status } & \multirow{2}{*}{ t } \\
\cline { 2 - 3 } & Married (n=103) & Single (n= 76) & \\
\hline Subjective Significance of Work & $6.50 \pm 1.69$ & $6.86 \pm 1.50$ & -1.47 \\
\hline Professional Ambition & $5.97 \pm 1.73$ & $6.28 \pm 1.69$ & -1.17 \\
\hline Tendency to Exert & $5.76 \pm 1.85$ & $5.51 \pm 1.93$ & .85 \\
\hline Striving for Perfection & $5.79 \pm 1.96$ & $5.99 \pm 1.89$ & -.68 \\
\hline Emotional Distancing & $4.88 \pm 1.45$ & $4.97 \pm 1.60$ & -.39 \\
\hline Resignation Tendencies & $4.43 \pm 1.86$ & $3.91 \pm 1.61$ & 1.94 \\
\hline Offensive Coping with Problems & $5.31 \pm 1.91$ & $5.34 \pm 1.78$ & -.11 \\
\hline Balance and Mental Stability & $5.79 \pm 1.94$ & $6.38 \pm 1.80$ & $-2.08^{*}$ \\
\hline Satisfaction with Work & $5.55 \pm 1.85$ & $5.39 \pm 1.65$ & .59 \\
\hline Satisfaction with Life & $5.83 \pm 1.57$ & $5.22 \pm 1.76$ & $2.40^{*}$ \\
\hline Experience of Social Support & $4.65 \pm 1.68$ & $4.37 \pm 1.45$ & 1.17 \\
\hline
\end{tabular}

Note. ${ }^{* * *} \mathrm{p}<.0001 ; * * \mathrm{p}<.001 ; * \mathrm{p}<.05, \mathrm{p}>.05$.

There was a significant difference between physical education teachers working at public and private schools on experience of social support $\left(t_{177}=-2.16, \mathrm{p}<.05\right)$ (Table 7$)$. 
Table 7. Means, standard deviations and independent t-test results for institution

\begin{tabular}{|l|l|l|l|}
\hline \multirow{2}{*}{ Work Related Behavior and Experience Patterns } & \multicolumn{2}{|c|}{ Institution } & \multirow{2}{*}{ t } \\
\cline { 2 - 3 } & Public (n= 68) & Private (n=111) & \\
\hline Subjective Significance of Work & $6.75 \pm 1.63$ & $6.59 \pm 1.61$ & .65 \\
\hline Professional Ambition & $5.91 \pm 1.85$ & $6.22 \pm 1.63$ & -1.15 \\
\hline Tendency to Exert & $5.71 \pm 1.86$ & $5.62 \pm 1.90$ & .29 \\
\hline Striving for Perfection & $5.49 \pm 1.85$ & $6.11 \pm 1.95$ & -2.11 \\
\hline Emotional Distancing & $4.99 \pm 1.64$ & $4.88 \pm 1.43$ & .43 \\
\hline Resignation Tendencies & $4.34 \pm 1.68$ & $4.13 \pm 1.84$ & .77 \\
\hline Offensive Coping with Problems & $5.34 \pm 1.92$ & $5.32 \pm 1.81$ & .08 \\
\hline Balance and Mental Stability & $6.13 \pm 1.76$ & $5.98 \pm 1.99$ & .51 \\
\hline Satisfaction with Work & $5.50 \pm 1.79$ & $5.48 \pm 1.76$ & .08 \\
\hline Satisfaction with Life & $5.44 \pm 1.53$ & $5.65 \pm 1.76$ & -.80 \\
\hline Experience of Social Support & $4.21 \pm 1.52$ & $4.73 \pm 1.60$ & $-2.16^{*}$ \\
\hline
\end{tabular}

Note. $* * * \mathrm{p}<.0001 ; * * \mathrm{p}<.001 ; * \mathrm{p}<.05, \mathrm{p}>.05$.

There was a significant correlation experience in service and tendency to exert $(\mathrm{r}=.15 ; \mathrm{p}$ $<.05)$, emotional distancing $(\mathrm{r}=-.14 ; \mathrm{p}<.05)$ and experience of social support $(\mathrm{r}=-.27 ; \mathrm{p}$ $<.00)$.

There was a significant negative correlation between age and experience of social support dimension $(\mathrm{r}=-.31 ; \mathrm{p}<.00)$ (Table 8). 
Table 8. Correlations between AVEM, age and experience in service $(n=179)$

\begin{tabular}{|c|c|c|c|c|c|c|c|c|c|c|c|c|c|}
\hline AVEM & 1 & 2 & 3 & 4 & 5 & 6 & 7 & 8 & 9 & 10 & 11 & $\mathbf{A}$ & $\mathbf{E}$ \\
\hline 1. SSW & 1 & $.54^{* * *}$ & $.59^{* * *}$ & $.43^{* * *}$ & $-.42^{* * * *}$ & .03 & $.40^{* * *}$ & .05 & $.34^{* * *}$ & .12 & -.03 & .00 & -.01 \\
\hline 2. PA & & 1 & $.67^{* * *}$ & $.61^{* * *}$ & $-.41^{* * *}$ & .02 & $.58^{* * *}$ & .07 & $.41^{* * *}$ & .10 & -.03 & -.09 & -.07 \\
\hline 3. TE & & & 1 & $.60^{* * *}$ & $-.56^{* * *}$ & $.15^{*}$ & $.55^{* * *}$ & -.01 & $.36^{* * *}$ & $.17^{*}$ & -.04 & .12 & $.15^{*}$ \\
\hline 4. SP & & & & 1 & $-.30^{* * *}$ & -.08 & $.62^{* * *}$ & $.16^{*}$ & $.51^{* * *}$ & $.23^{* *}$ & .08 & -.09 & -.06 \\
\hline 5. ED & & & & & 1 & $-.31^{* * *}$ & $-.28^{* * *}$ & $.30^{* * *}$ & $-.16^{*}$ & -.03 & .00 & -.06 & $-.14^{*}$ \\
\hline 6. RT & & & & & & 1 & $-.15^{*}$ & $-.44^{* * *}$ & $-.18^{*}$ & -.12 & $-.15^{*}$ & .01 & .04 \\
\hline 7. ОСР & & & & & & & 1 & $.30^{* * *}$ & $.52^{* * *}$ & $.26^{* * *}$ & .06 & .04 & .02 \\
\hline 8. BMS & & & & & & & & 1 & $.16^{*}$ & $.22^{* *}$ & .11 & -.02 & -.09 \\
\hline 9. SW & & & & & & & & & 1 & $.36^{* * *}$ & .08 & .13 & .13 \\
\hline 10. SL & & & & & & & & & & 1 & $.38^{* * *}$ & .04 & .05 \\
\hline 11. ESS & & & & & & & & & & & 1 & $-.31^{* * *}$ & $-.27^{* * *}$ \\
\hline $\mathbf{A}$ & & & & & & & & & & & & 1 & $.927^{* * *}$ \\
\hline $\mathbf{E}$ & & & & & & & & & & & & & 1 \\
\hline
\end{tabular}

Note. ${ }^{* * *} \mathrm{p}<.0001 ; * * \mathrm{p}<.001 ;{ }^{*} \mathrm{p}<.05, \mathrm{p}>.05$.

AVEM $=$ Work Related Behavior and Experience Patterns, SSW $=$ Subjective Significance of Work, $\mathrm{PA}=$ Professional Ambition, $\mathrm{TE}=$ Tendency to Exert, $\mathrm{SP}=$ Striving for Perfection, ED $=$ Emotional Distancing, $\mathrm{RT}=$ Resignation Tendencies, OCP $=$ Offensive Coping with Problems, BMS = Balance and Mental Stability (BMS), SW = Satisfaction with Work, SL = Satisfaction with Life, ESS $=$ Experience of Social Support, A = Age, E = Experience.

\section{Discussion}

The aim of this research was to determine work-related behaviors and experience patterns of physical education teachers and to analyze them according to the individually burnout factors. This and further results may inform future intervention strategies targeting teacher individually factors of burnout experiences.

The risk level of physical education teachers (Type A and Type B) (30.7\%) participating in the study was lower than the research on teachers (41.7\%) (Kiremitçi et al., 2014) and the research on physical education teachers (44.8\%) (Kiremitci \& Gençer, 2014). In addition, the low burnout levels $(5.6 \%)$ occur on the participants showed similarities with previous studies conducted in Turkey and abroad (Alkan et al., 2011; Fejgin et al., 1995; Koustelios \& Tsigilis, 2005). The low levels of burnout syndrome observed along with the low risk group level may be due to the teachers' lack of knowledge and skills that serve to fulfill the requirements of their profession or they do not know how to use their knowledge and skills. 
In the dimension of balance and mental stability, while male teachers have higher scores than female teachers and single teachers also score higher than married teachers. Kiremitçi and Gençer (2014) found the same results in their research. The reason behind the higher scores of single teachers may be that they have increased their capacity to deal with difficulties individually.

It was found that teachers working in private schools had higher striving for perfection and experience of social support scores than teachers working in public schools. The reason for the high scores seen in teachers working in private schools may be due to privatization. As a result of the privatization processes (Evans \& Davies, 2015), it has been observed that teachers are as knowledge broker (Macdonald, 2015).

It was found that as the age and experience of teachers increased, their experience of social support scores decreased. In addition, it was found that as teachers' experience increased, their tendency to exert and their emotional distancing decreased. It may be due to expectations of loneliness rather than social support experience on high age and experienced teachers (Kaya \& Erdoğan, 2020). Another reason may be that students were more resistant to high age and experienced teachers (Arıkan, 2020).

\section{Conclusion and Recommendations}

In conclusion, these low levels of burnout may be due to physical education teachers' habituation of exercise (Kızıldağ, 2014; Koruç \& Bayar, 2004) which is one of their individual coping strategies. The results of marital status, gender, institution, age, and experience in service which are classified as factors that affect burnout individually (Dalkıliç, 2014), it can be said that physical education teachers were similarly affected by professional burdens and responsibilities.

Convenience sampling method was used in this research. This limitation can be overcome by using one of the random sampling methods (Şenol, 2012) in further studies. In further studies, work related behaviors and experience patterns can be examined with more than one occupational group (Voltmer, Spahn, Schaarschmidt, \& Kieschke, 2011) in terms of exercise behavior including physical education teachers.

\section{References}

Alkan, E., Yildiz, S. M., \& Bakir, M. (2011). Mobbingin beden eğitimi ve spor öğretmenlerinin tükenmişliği üzerine etkisi. Selçuk Üniversitesi Beden Eğitimi ve Spor Bilim Dergisi, 13(3), 270-280.

Arıkan, G. (2020). Examination of student resistance behaviors towards physical education and sports teachers in the teaching-learning process. Journal of Educational Issues, 6(2), 107-117. https://doi.org/10.5296/jei.v6i2.17432

Brante, G. (2009). Multitasking and synchronous work: Complexities in teacher work. Teaching and Teacher Education, 25(3), 430-436. https://doi.org/10.1016/j.tate.2008.09.015

Brudnik, M. (2009). Perception of self-efficacy and professional burnout in general education 
teachers. Human Movement, 10(2), 170-175. https://doi.org/10.2478/v10038-009-0013-3

Büyüköztürk, Ş., Çakmak, E. K., Akgün, Ö. E., Karadeniz, Ş., \& Demirel, F. (2016). Bilimsel araştırma yöntemleri (20th ed.). Ankara: Pegem Akademi. https://doi.org/10.14527/978994 4919289

Dalkılıç, O. S. (2014). Çalışma hayatında tükenmişlik sendromu: tükenmişlikle mücadele teknikleri (2nd ed.). Ankara: Nobel Yayınc1lık.

Demirhan, G. (2006). Spor eğitiminin temelleri. Ankara: Spor Yayınevi \& Bağırgan Yayınevi.

Doğan, S., Demir, S. B., \& Pınar, M. A. (2014). $4+4+4$ kesintili zorunlu eğitim sisteminin sınıf öğretmenlerinin görüşleri doğrultusunda değerlendirilmesi. Illköğretim Online, 13(2), 503-518.

Evans, J., \& Davies, B. (2015). Physical education, privatisation and social justice. Sport, Education and Society, 20(1), 1-9. https://doi.org/10.1080/13573322.2014.942624

Fejgin, N., Ephraty, N., \& Ben-Sira, D. (1995). Work environment and burnout of physical education teachers. Journal of Teaching in Physical Education, 15(1), 64-78. https://doi.org/ 10.1123/jtpe.15.1.64

Gençer, R. T., Boyacıŏ̆lu, H., Kiremitçi, O., \& Doğan, B. (2010). Psychometric properties of work-related behavior and experience patterns (AVEM) scale. Hacettepe University Journal of Education, 38, 138-149.

Grayson, J. L., \& Alvarez, H. K. (2008). School climate factors relating to teacher burnout: A mediator model. Teaching and Teacher Education, 24(5), 1349-1363. https://doi.org/10.1016/ j.tate.2007.06.005

Jepson, E., \& Forrest, S. (2006). Individual contributory factors in teacher stress: The role of achievement striving and occupational commitment. British Journal of Educational Psychology, 76(1), 183-197. https://doi.org/10.1348/000709905X37299

Kalaycı, Ş. (2016). SPSS uygulamalı çok değişkenli istatistik (7th ed.). Ankara: Asil Yayın Dağıtım.

Kaya, K., \& Erdoğan, Ç. H. (2020). Investigation of loneliness levels of physical education teachers. African Educational Research Journal, 8(2), 239-243. https://doi.org/10.30918/aerj. 82.20.060

Kieschke, U., \& Schaarschmidt, U. (2008). Professional commitment and health among teachers in Germany: A typological approach. Learning and Instruction, 18, 429-437. https://doi.org/10.1016/j.learninstruc.2008.06.005

Kiremitci, O., \& Gençer, R. T. (2014). Work related behaviors and experience patterns of physical education teachers. International Online Journal of Educational Sciences, 6(3), 581-590. https://doi.org/10.15345/iojes.2014.03.007

Kiremitçi, O., Gençer, R. T., \& Demiray, E. (2014). Investigation of work related behaviors 
and experience patterns of teachers according to various variables. Journal of Research in Education and Teaching, 3(2), 66-74. https://doi.org/10.15345/iojes.2014.03.007

Kızıldağ, D. (2014). Çalışan stresi, olumsuz işgören tutumları ve davranışları. In B. Özkara (Ed.), Endüstri ve örgüt psikolojisine giriş (6th ed., pp. 247-279). Ankara: Nobel Akademi Yayıncılik.

Koruç, Z., \& Bayar, P. (2004). Egzersizin depresyon tedavisindeki yeri ve etkileri. Hacettepe Journal of Sport Sciences, 15(1), 49-64.

Koustelios, A., \& Tsigilis, N. (2005). The relationship between burnout and job satisfaction among physical education teachers: A multivariate approach. European Physical Education Review, 11(2), 189-203. https://doi.org/10.1177/1356336X05052896

Macdonald, D. (2015). Teacher-as-knowledge-broker in a futures-oriented health and physical education. Sport, Education and Society, 20(1), 27-41. https://doi.org/10.1080/ 13573322.2014 .935320

Maslach, C. (1982). Burnout: The cost of caring. Los Altos, CA: ISHK.

OECD. (2005). Teachers matter: Attracting, developing and retaining effective teachers. OECD Publications.

Pirrie, A. M., \& Lodewyk, K. R. (2012). Investigating links between moderate-to-vigorous physical activity and cognitive performance in elementary school students. Mental Health and Physical Activity, 5, 93-98. https://doi.org/10.1016/j.mhpa.2012.04.001

Schaarschmidt, U., \& Fischer, A. W. (1997). AVEM-ein diagnostisches instrument zur differenzierung van typen gessundheitsrelevanten verhaltens und erlebens gegenüber der arbeit. Zeitschrift Für Differenzielle Diagnostische Psychologie, 18(3), 151-163.

Schaarschmidt, U., \& Fischer, A. W. (2011). Work-related behaviour and experience patterns. Mödling, Austria: Schuhfried GmbH. https://doi.org/10.1037/t10903-000

Şenol, Ş. (2012). Araştırma ve örnekleme yöntemleri (1st ed.). Ankara: Nobel Akademi Yayıncilik.

Sucuoglu, E., \& Atamturk, H. (2020). Correlation relation between professional qualifications of physical education teachers and students' attitudes towards physical education classes. Pedagogy of Physical Culture and Sports, 24(1), 44-47. https://doi.org/10.15561/18189172. 2020.0107

Tabachnick, B. G., \& Fidell, L. S. (2013). Using multivariate statistics (6th ed.). Boston: Allyn and Bacon.

Voltmer, E., Spahn, C., Schaarschmidt, U., \& Kieschke, U. (2011). Work-related behavior and experience patterns of entrepreneurs compared to teachers and physicians. International Archives of Occupational and Environmental Health, 84, 479-490. https://doi.org/10.1007/ s00420-011-0632-9 
Notes

This article was produced from master's thesis of Ramazan Taşçığlu titled "Investigation of Work-Related Behaviors and Experience Patterns of Physical Education Teachers According to the Different Variables (Sample of İzmir).

\section{Copyright Disclaimer}

Copyright for this article is retained by the author(s), with first publication rights granted to the journal.

This is an open-access article distributed under the terms and conditions of the Creative Commons Attribution license (http://creativecommons.org/licenses/by/3.0/). 